\title{
Corrigendum: Macroscopic ordering of helical pores for arraying guest molecules noncentrosymmetrically
}

Chunji Li, Joonil Cho, Kuniyo Yamada, Daisuke Hashizume, Fumito Araoka, Hideo Takezoe, Takuzo Aida \& Yasuhiro Ishida

Nature Communications 6:8418 doi: 10.1038/ncomms9418 (2015); Published 29 Sep 2015; Updated 26 Oct 2015

The Cambridge Crystallographic Data Centre (CCDC) accession code provided in this article is incorrect; the correct deposition number is 1059112 .

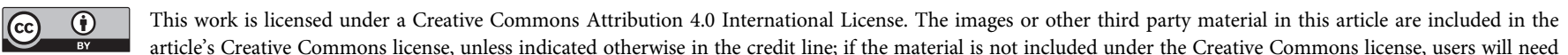
to obtain permission from the license holder to reproduce the material. To view a copy of this license, visit http://creativecommons.org/licenses/by/4.0/ 